\title{
Viewpoint: A view on species additions and deletions and the balance of nature
}

\author{
HYRUM B. JOHNSON AND HERMAN S. MAYEUX
}

\begin{abstract}
Authors are ecologist and range scientist, USDA, Agricultural Research Service, 808 East Blackland Rd., Temple, Tex. 76502 .
\end{abstract}

\begin{abstract}
Popular assumptions about ecosystem stability and the delicate balance of nature are found lacking when examined in terms of paleoecological, historical and current biochronological, and biogeographical sequences in a wide variety of environments. Species composition of vegetation varies continuously in time as well as space in the absence of acute perturbations. Species have been added to or removed from ecosystems without greatly affecting ecosystem function. Natural ecosystems exhibit greater stability (inertia) in physiognomic structure and functional processes than in species composition. For instance, creosotebush became dominant over many millions of hectares of the Chihuahuan, Sonoran, and Mojave Deserts over a short period of 11,000 years, but a limited number of generations precludes establishment of highly integrated and biologically regulated communities by co-evolution. Dramatic shifts in species composition of eastern deciduous forests of North America occurred in prehistory and continue into the present. Similar changes are noted in the constant assembling and reassembling of species in the purportedly ancient and stable forests of the tropics. Numerous introductions with few extinctions in the flora of California have increased species richness and probably diversity, and many recent additions are primary contributors to ecosystem productivity. Recognition that rangeland ecosystems persist in unstable rather than stable species compositions provides both a challenge and an opportunity for natural resource management. The challenge is to develop new management principles that incorporate nonequilibrium theory. The opportunity is the promotion of policies and regulations that more closely reflect reality.
\end{abstract}

Key Words: ecology, paleoecology, biogeography, climax, vegetation change, biological control, extinction, co-evolution, creosotebush

In this time of increased sensitivity over the health of the planet, an accurate understanding of how the earth's ecosystems work becomes of paramount importance. Rangelands count significantly in the global perspective since they occupy approximately $40 \%$ of the earth's land surface. Westman (1977) considers the structural components of ecosystems to be nature's free "goods," e.g., forage, timber, fish, etc., that are marketable products, and the functional processes which drive them as providing nature's free "services," i.e., fixation of atmospheric nitrogen, energy capture through photosynthesis, breakdown of pollutants, maintenance of oxygen levels in the air, and other processes that insure "clean air, pure water, and a green earth." Westman asks the question, "How much are nature's services worth?" and Pimentel et al. (1980) respond by calculating some of the values for the United States in economic terms and conclude that they are enormous. Any prospects of changes in the goods and services of ecosystems arc thereforc proper causes for concern.

Drs. Lloyd Andres, C. Jack DeLoach, D. Lynn Drawe, Peter Harris, William A Laycock, William Pamer. Philip Sims, Fred Smeins, A.J. Svejcar, and Philip V Manuscript accepted 12 October 1991.
Vegetation forms the matrix of terrestrial ecosystems. Changes in the physiognomic structure and/ or species composition of vegetation provide immediate evidence of ecosystem change. Such changes can be framed in the general ecosystem concepts of stability, diversity, and productivity. Our attention will be directed toward stability, which has several conceptual components and in theory is often linked closely with diversity and productivity. Ecosystem stability has at least 2 principal aspects: that related to the toughness of the system, i.e., how much force is required to change its structure and/or function, and that related to the dynamics of change after an alteration has occurred. Westman (1978) discusses the first in terms of inertia and the second under the heading resilience, which he separates into elasticity, amplitude, hysteresis, and malleability.

The usual perception of inertial stability is in terms of stable species composition, which constitutes, a self-sustaining system according to the "balance of nature" paradigm. We propose a second, or alternative, view of a self-sustaining system in terms of physiognomic structure and functional processes in which various species with similar physiognomy and function are interchangeable. Such a system may have high inertial stability even with the coming and going of species. As for the resilience of altered ecosystems, elasticity (the capacity for recovery) and malleability (the capacity for establishing a new structural or functional balance) are perhaps the most significant aspects of the concept in relation to rangelands.

Vegetation changes are occurring on rangelands throughout the western United States and throughout the world (Mayeux et al., in press). Foreign plant species have invaded the grasslands of California and the steppes of the Great Basin to the point of becoming major components of the vegetation (Burcham 1957, Mack 1986). Native woody plants have increased at the expense of native grasses over vast areas of southwest North America (Branson 1987). These changes are widely perceived as unfortunate. This sentiment seems to depend in large part on the assumptions that species composition at the time of settlement must be perpetuated, that native species are essential components of delicately balanced co-evolved ecosystems that are stable through time and replicated in space (Andres 1981a, 1981 b; Pemberton 1984), and that native species and introduced species are fundamentally different in the roles they play in ecosystems (Howarth 1983). Indeed Andres (1981b) maintains that "Ecological conflicting interests arise in the belief that all elements of an ecosystem are interrelated and that removal of a plant species from an area, especially a native species, will trigger some unknown and unwanted reactions." Howarth (1983) speaks of "biological pollution" defined as "the establishment in the wild of foreign or non-native organisms." Both Andres and Howarth ascribe much higher "environmental value" to native organisms than to those that are alien. Temple (1990) recommends the eradication of exotic organisms and argues that we are remiss in not initiating such programs. Ehrlich (1990) maintains that 
"overgrazing of public lands in the West in both riprian and non-riprian habitat has become a major factor in reducing the diversity of plants" and predicts that "accumulated losses of populations and ecosystem fragments could soon add up to the permanent disappearance of many species and communities."

Recent research concerning both the indirect effects of increasing atmospheric $\mathrm{CO}_{2}$ levels on plants through climate change and the direct effects represented by $\mathrm{CO}_{2}$ fertilization have prompted several authors to predict future dramatic changes in the structure of native vegetation (Bazzaz and Garbut 1988, Overdieck and Reining 1986) and the relocation of physiognomic structure types (Emanuel et al. 1985, Idso and Quinn 1983). It has been suggested that global climate change may accelerate rates of plant extinction, with concommitant and possibly catastrophic shifts in ecosystem structure and function (i.e., several authors in World Wildlife Fund 1988, Peters 1990). The possibility of serious consequences associated with global change is an example of an issue that can be assessed by consideration of recent changes in vegetation characteristics.

\section{Vegetation Theory}

These views are most easily understood in terms of Clementsian climax vegetation theory (Clements 1916, 1920; Weaver and Clements 1938; Dyksterhuis 1946), in which vegetation units are perceived as highly integrated and regulated entities serving as the matrix for biotic assemblages representing discrete steps of biological organization. The theory, in its extreme form, assumes that vegetation units arise, grow, mature and die through the processes of ecological succession (Clements 1916). Once attained, climaxes maintained themselves by perpetuating the more or less final, stable condition. Stability in structure is viewed in terms of species composition because the occurrence of each species in its proper proportion is important in defining the climax. Climax vegetation is considered ancient in age. Climatic change results in death of the climax organism or its shift intact to a new location, trailing the climate.

The climax concept has had enormous appeal to those working in applied fields of biology where there is a need to relate vegetation dynamics to other considerations such as in animal population ecology and range management (Allee et al. 1949, Price 1975, Meeker and Merkel 1984). Sampson (1919) wrote a germinal paper that introduced the then-current principles of vegetation dynamics to the developing discipline of range management. His paper, entitled "Plant Succession in Relation to Range Management," is Clementsian to the core. Sampson is properly regarded as the father of range management and wrote the first textbook on the subject (1923). From this early beginning, Clement's view on climax and succession became an integral part of range management philosophy. This philosophy was further formalized by Dyksterhuis (1949), who ingeniously extended the climax concept to systematically evaluate the condition and trend of rangeland vegetation with regard to management practices. This resulted in the institutionalization of the concept as national policy for dealing with rangeland resources (Soil Conservation Service 1976).

Clementsian climax theory has not been nearly so readily accepted in its home discipline of plant ecology although it is one of the most discussed subjects in plant ecological literature. Differences between field observations and the theoretical climax relationships proposed in Sampson's germinal paper were exposed by Ellison's classical work on the vegetation of the Wasatch Plateau (Ellison 1954). Ellison reconsidered the early sites used by Sampson in his pioneering work and argued that Sampson had erred in misreading successional sequences and the true climax. He proposed a more complex climax-patterned landscape. Subsequent observations of vegetation changes on some of these same plots show that a flux in species composition is continuing through time and is not stabilizing as Ellison concluded it should be (Johnson 1964).

The antithesis of the Clementsian climax theory is Gleason's individualistic hypothesis on the origin of plant communities (Gleason 1926). Current theoretical research on the nature of vegetation leans much more strongly in the direction taken by Gleason than by Clements (Miles 1979, McIntosh 1980, Vale 1982) and continues to evolve as the continuum concept (Austin and Smith 1989). Graham and Grimm (1990) conclude that the individualistic hypothesis is most appropriate in predicting vegetation responses to rapid climate change associated with possible global warming. Davis (1989) considered the implications of recent paleoecological insights for predicting ecological responses to global change and emphasized the individualistic responses of species to changes in climate. She noted that geographical distributions of entire assemblages will not be shifted intact, raising questions concerning the fate of individual species and effects of additions or deletions of species on ecosystems.

\section{Importance of Theory}

Theoretical questions on this matter should not be dismissed has having significance only in academia. Answers given to questions regarding ecosystem response to grazing and global change are influenced by the underlying theoretical view. Appropriate answers depend in large part upon a correct understanding of fundamental principles that determine vegetation structure. The accepted theory of vegetation dynamics and ecosystem function strongly influences public policy and law in essentially all matters concerning our environment, and the efficacy of such policy and law depends on whether or not the theory is a fundamentally sound.

Furthermore, theories change as new understanding is gained. The critical assertions concerning balanced, co-evolved systems, extinctions, and biological pollution cited above seem to presuppose certain things about species, communities, and ecosystems that need to be examined more closely in terms of current knowledge and theory, particularly in regard to community structure, vegetation development, and ecosystem equilibria. Is the loss a species on rangeland likely? If so, will it have dire ecological consequences? To that end, we consider in detail several examples of historical shifts in species composition and qualitatively assess the nature of their impacts.

\section{The Case of Creosotebush}

Creosotebush [ Larrea tridentata (Ses. \& Moc. Ex. DC.) Cov.] is the principal component of the vegetation of the Chihuahuan, Sonoran and Mojave Deserts (Fig. 1). On each desert, it is represented by a different chromosome race, diploid on the Chihuahuan, tetraploid on the Sonoran, and hexaploid on the Mojave (Yang 1970). Larrea tridentata has close taxonomic affinities with Larrea divaricata Cav. of the Argentine desert in South America and has been considered conspecific with it (Hunziker et al. 1972). $L$. divaricata in South America is diploid like the race of $L$.tridentata of the Chihuahuan Desert. The generally accepted interpretation of events connecting them and leading to the present distribution pattern is that $L$. divaricata from South America (more than 1 species of Larrea occurs there) was introduced by long distance dispersal to the Chihuahuan Desert in North America. From there it spread northwestward to the Sonoran and Mojave Deserts, undergoing cytogeographic differentiation in the process (Wells and Hunziker 1976). The most significant aspect of this spread for our consideration is the time frame in which it occurred.

A method of dating the expansion phase was fortuitously provided by the collecting and stockpiling activities of pack rats ( NeOtoma sp.) (Wells and Jorgensen 1964). Carbon-14 dates of materials in Neotoma nests span the period from present to over 40,000 


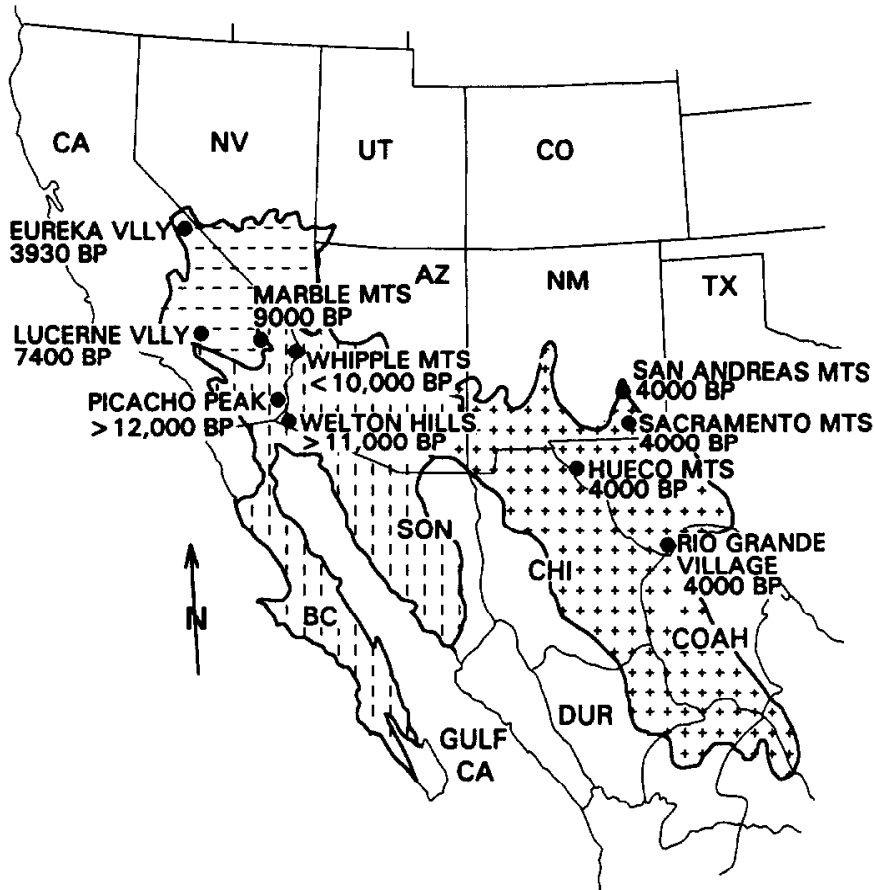

Fig. 1. The Deserts of the southwestern United States and Mexico; horizontal dashed lines identify the Mojave Desert, vertical dashed lines the Sonoran Desert, and + symbol the Chihuahuan Desert. Locations with appropriate series of ${ }^{14} \mathrm{C}$ dated packrat middens are identified with the approximate year before present (BP) that creosotebush arrived at that point. AZ (Arizona), BC (Baja Calli.), CA (California), CHI (Chihuahua), COAH (Coahuila), DUR (Durango), NM (New Mexico), NV (Nevada), TX (Texas), SON (Sonora), UT (Utah).

years ago (Wells and Berger 1967).

Modern midden deposits in creosotebush dominated areas contain an abundance of creosotebush fragments (Wells 1974, 1976; Cole and Webb 1985). In the fossil middens older than 11,000 years, there is essentially a dearth of creosotebush even though some other modern desert species' macro-fossils (e.g., Agave, Yucca, and Opuntia) do occur (Wells 1983a, Van Devender 1986). This pronounced pattern was central to the suggestion of Wells and Hunziker (1976) of the possibility of a relatively late introduction of creosotebush from South America. The actual date of introduction is difficult to establish but the rate and direction of spread after its confirmed presence in North America can be determined.

The oldest macrofossils of creosotebush reported so far are from low rainfall, low elevational portions of the Sonoran Desert near the head of the Gulf of California (Picacho Peak, 12,000 B.P.; Fig. 1). Creosotebush begins to appear consistently and in quantity in middens of this region about 11,000 years ago (Table 1). Younger ages are associated with deposits toward the northwest: Marble Mountains, 9,000 years before present (BP); Lucerne Valley, 7,400 years BP; Eureka Valley, 4,000 years BP. An invasion time series from the mouth of the Colorado River in the Sonoran Desert to the northern limit of the present creosotebush distribution in the Mojave Desert is thus evident. In the Chihuahuan Desert, creosotebush arrived at its northern limit at about the same time as in the Mojave, approximately 4,000 years ago (Table 1 ). We find no reports of macrofossils of creosotebush from the central or southern Chihuahuan Desert areas, even though cytogeographic patterns strongly suggest that this is the area where the oldest ancestral fossils should be sought.

The present north-south range of creosotebush from approximately $23^{\circ}$ to $37^{\circ}$ latitude spans a diagonal distance of about 2,000 $\mathrm{km}$. We estimate the area of the 3 deserts invaded at around 100 million ha. Using a time frame of 7,000 years, from $11,000 \mathrm{BP}$ to $4,000 \mathrm{BP}$, the rate of movement required to attain the distribution
Table 1. Locations and carbon-14 ages in years before present (yr BP) of plant macrofossil assemblages preserved in packrat middens from the Mojave, Sonoran and Chihuahuan Deserts. The data are selected to show the northerly migration of Larrea tridentata by bracketing the time of arrival of Larrea in each locality.

\begin{tabular}{|c|c|c|c|}
\hline \multirow[b]{2}{*}{ Location } & \multicolumn{2}{|c|}{ Larrea } & \multirow[b]{2}{*}{ Comments (Reference') } \\
\hline & Absent & Present & \\
\hline \multirow{2}{*}{\multicolumn{4}{|c|}{$\ldots \ldots$ yr BP $\ldots \ldots$}} \\
\hline & & & \\
\hline $\begin{array}{l}\text { Eureka Valley CA } \\
\text { Mojave northern } \\
\text { limit }\end{array}$ & $\begin{array}{l}6,795 \\
5,595 \\
5,435(?)\end{array}$ & $\begin{array}{l}3,930 \\
2,635 \\
1,580\end{array}$ & $\begin{array}{l}\text { Low initial abundance } \\
\text { but increases } \\
\text { markedly in time (1) }\end{array}$ \\
\hline $\begin{array}{l}\text { Ord Mnt. CA } \\
\text { Lucerne Valley CA } \\
\text { south-central Mojave }\end{array}$ & $\begin{array}{l}9,140 \\
7,800\end{array}$ & $\begin{array}{l}7,400 \\
5,880\end{array}$ & $\begin{array}{l}\text { Sites located in } \\
\text { close proximity }(2,3)\end{array}$ \\
\hline $\begin{array}{l}\text { Marble Mnts. CA } \\
\text { transition from } \\
\text { Mojave to Sonoran }\end{array}$ & $\begin{array}{l}10,465 \\
10,210 \\
9,515(?) \\
8,905\end{array}$ & $\begin{array}{l}8,925(?) \\
7,930 \\
5,520 \\
4,475\end{array}$ & $\begin{array}{l}\text { Low initial abundance } \\
\text { but increases to } \\
\text { dominance (1) }\end{array}$ \\
\hline \multicolumn{4}{|l|}{ Sonoran } \\
\hline $\begin{array}{r}\text { Whipple Mnts. CA } \\
\text { northern Sonoran }\end{array}$ & 9,980 & - & Not reported (4) \\
\hline $\begin{array}{l}\text { New Water Mnts. AZ } \\
\text { northern Sonoran }\end{array}$ & 7,870 & 10,800 & $\begin{array}{l}\text { Persisted longer } \\
\text { at some sites }(4,5)\end{array}$ \\
\hline $\begin{array}{l}\text { Welton Hills AZ } \\
\text { southwestern AZ }\end{array}$ & & 10,580 & than at others (2) \\
\hline $\begin{array}{l}\text { Picacho Peak CA } \\
\text { southeastern CA }\end{array}$ & - & 12,730 & $\begin{array}{l}\text { Most arid part of } \\
\text { Sonoran Desert; has } \\
\text { oldest fossils (6) }\end{array}$ \\
\hline \multicolumn{4}{|l|}{ Chihuahuan } \\
\hline San Andres Mnts. NM & 6,330 & 4,340 & $\begin{array}{l}\text { Indicates a near } \\
\text { northern limit } \\
\text { of recent occupation }\end{array}$ \\
\hline $\begin{array}{c}\text { Sacramento Mnts. NM } \\
\text { southcentral NM }\end{array}$ & 4,200 & 3,300 & in the Chihuahuan $(7,8$ \\
\hline $\begin{array}{l}\text { Hueco Mnts. TX } \\
\text { northwest TX }\end{array}$ & 6,360 & 3,650 & $\begin{array}{l}\text { North to South age } \\
\text { difference not }\end{array}$ \\
\hline $\begin{array}{l}\text { Rio Grande Village } \\
\text { southwest TX }\end{array}$ & 5,500 & 4,300 & evident (9) \\
\hline
\end{tabular}

'References: (1) Spaulding 1980, (2) Wells and Berger 1967, (3) King 1976, (4) Van Devender 1977, (5) Van Devender and Spaulding 1979, (6) Cole 1986, (7) Van Devender, Betancourt and Wimberly 1984, (8) Van Devender and Toolin 1983, (9) Van Devender 1986.

evident in the macrofossil record, assuming a south to north expansion, would be on the order of $280 \mathrm{~m} / \mathrm{yr}$ or $2.8 \mathrm{~km} /$ decade. The occupancy of new land area would need to proceed at an impressive rate of about $16,000 \mathrm{ha} /$ year. Such dynamic change casts serious doubt on popular suppositions about long term balance and equilibrium in the natural landscape.

Another important consideration in judging vegetation equilibria is the life span characteristics of individual plants. Creosotebush plants in the Mojave Desert develop clonally and live to great age (Vasek et al. 1975, Sternberg 1976). Clones, composed of closely spaced stems, are readily distinguished on aerial photographs as irregular clumps, often donut-shaped (Fig. 2). Growing clones expand outwardly around the periphery, ultimately leaving a hollow cluster. Clone age can be calculated from clone diameter and rate of expansion. Expansion rates have been estimated using a variety of techniques, including time lapse photography, radio carbon dates of dead clonal segments and radial stem growth-ring increments (Johnson and Vasek 1975, Vasek 1980). Clone diameter growth rates vary with substrates but are generally on the order of $2 \mathrm{~mm} / \mathrm{yr}$. Clones up to $21 \mathrm{~m}$ diameter are known. Extrapolated ages for the older individuals in the vicinity of Lucerne Valley, California, range from 6,000 to 11,000 years depending on the growth rate used (Sternberg 1976, Vasek 1980). Radiocarbon dates 


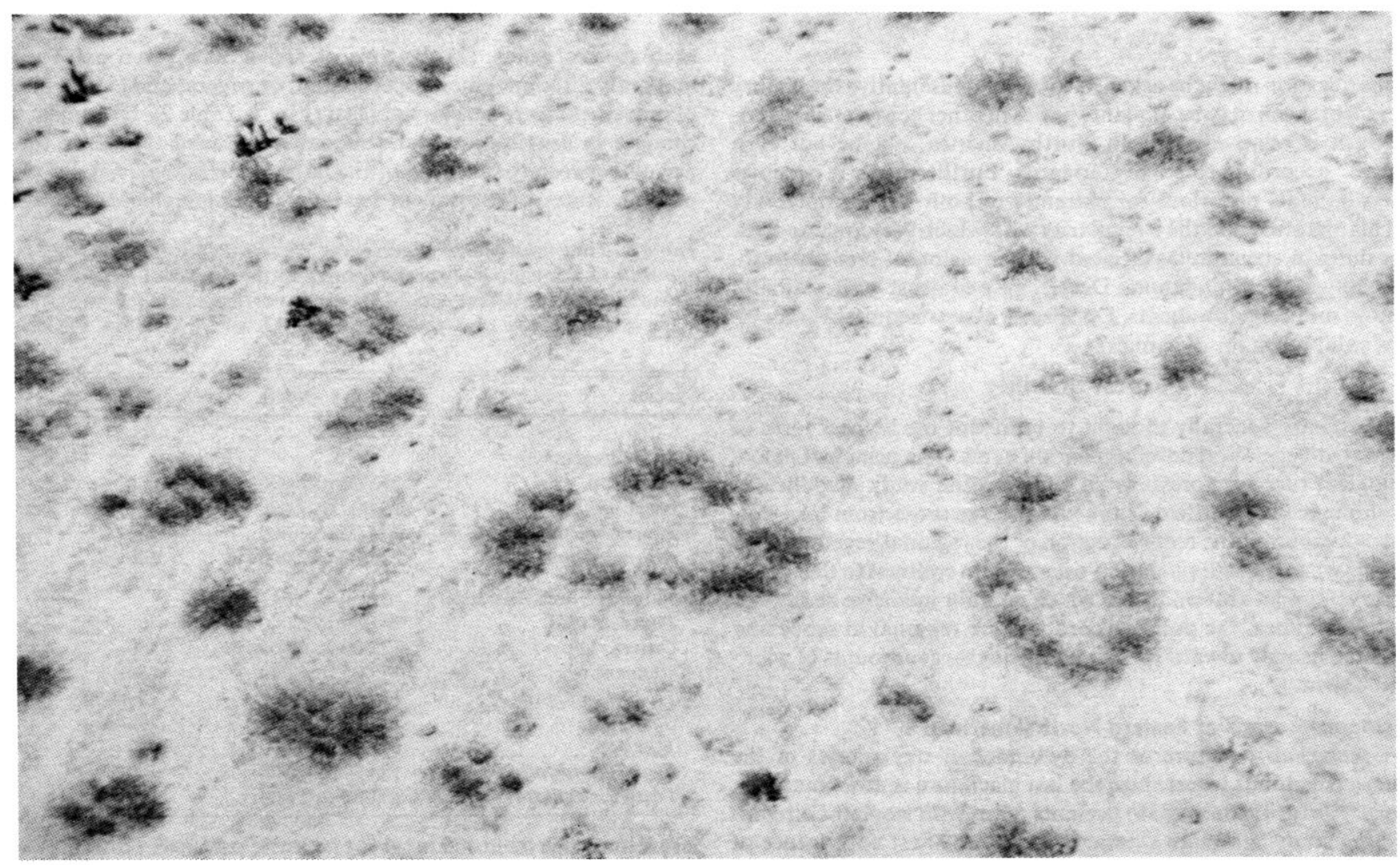

Fig. 2. Aerial view of creosotebush (larger shrubs) in the Mojave Desert. All stages of development of vegetative clones are present, from single-stemmed plants to multiple-stemmed, hollow-centered clumps. The large doughnut shaped clone in the center is about $7 \mathrm{~m}$ across and its age is estimated to be about $5,000 \mathrm{yr}$.

of pack rat middens from the same vicinity show creosotebush present at 5,800 years BP (King 1976) and 7,400 years BP (Wells and Berger 1967) but absent earlier than 7,800 years BP (Table 1). This suggests that the older clones may represent the initial establishment of creosotebush in this part of the Mojave Desert (Johnson 1976) and the strong possibility that the genotype of the first generation is still present. Their presence has an obvious bearing on the extent to which the process of co-evolution might be operative as a mechanism for establishing an integrated, functional community equilibrium.

The concept of co-evolution relies on the idea that compensating, inheritance-based adjustments occur in successive generations between, or among, interacting species so as to allow them to coexist. Opportunity for such integration is clearly limited in this case due to a small number of creosotebush generations. Indeed, an argument for the recency of creosotebush in North America is suggested by the presence of fewer co-evolved insects and reduced herbivory by insects in North America than in Argentina where creosotebush is purported to have originated (Cordo and DeLoach, in press). The success of creosotebush is apparently due more to preadaptation than to co-evolution and its preadaptive characteristics are more attuned to the physical environment than to biotic integration.

Creosotebush has not been alone in exhibiting marked spatial and temporal changes as demonstrated by Spaulding (1990) in his presentation of the dynamic history of several other desert species. Cole and Webb (1985) sampled 8 fossil and 5 modern pack rat middens in the central Mojave at elevations that included the upper limit of creosotebush and the lower limit of blackbrush (Coleogyne ramosissima J. Torr.). Creosotebush was present in all samples, the oldest dating back 2,235 years. Blackbrush was not present in middens older than 270 years, even in areas where today it is the dominant species. This provides evidence that shifts in species composition were occurring up through the period just prior to European settlement. In the Chihuahuan Desert, the invasion of creosotebush has continued into historical times. Buffington and Herbel (1965) documented extensive increases in the area occupied by woody species, primarily creosotebush and mesquite (Prosopis glandulosa Torr.) on the Jornada Experimental Range in New Mexico over the past century. York and Dick-Peddie (1969) showed the same spread for localities scattered all across southern New Mexico. The increase in area occupied by creosotebush primarily represents encroachment on desert grassland and, to a lesser extent, encroachment on areas dominated by other shrubs such as mesquite (York and Dick-Peddie 1969).

A common explanation for the increasing abundance of shrubs is that grazing of the desert grassland by introduced livestock upset a "balance." An alternative view is that a balance never existed in the first place and that the introduction of domestic animals only added another environmental factor that tended to modify the rate rather than the direction of changes that were already in progress. Smeins (1983) emphasizes the importance of a long-term historical perspective for understanding the current "brush problem." The region of documented brush invasion in New Mexico is near the northern limit of creosotebush's distributional range and may be interpreted as the leading front of creosotebush invasion in the Chihuahuan Desert that has been proceeding for about 5,000 years, since the mid-holocene (Fig. 1, Table 1).

The documented dynamics of creosotebush populations in 3 desert ecosystems indicate low inertial stability in the "pristine" state, both in terms of dominant species composition and functional processes. The former is implied by the rapid invasions of creosotebush and the latter is implied by shifts in physiognomic structure, from woodland to scrub in the Mojave and Sonoran Deserts and from grassland to scrub in the Chihuahuan Desert. In terms of resilience, these systems would rank low in elasticity but 
high in malleability.

The question might be asked as to how representative the history of creosotebush may be of plant species in other ecosystems. Creosotebush is relatively new in North America, maybe not even "native" according to some standards. Furthermore, it occupies desert habitats notorious for extremes of both water availability and temperature and the irregularity with which they are imposed. The shifts in structure associated with invasion of creosotebush, especially in the Chihuahuan Desert, may contrast with examples in more mesic environments. Do species of more equitable ecosystems exhibit similar dynamics?

\section{Forest Stability}

Forests are generally thought to represent the highest form of integrated vegetation development on earth. The principal paleoecological tool for forests is palynology, the study of pollen in chronologically stratified sediments such as those from lake bottoms, that permit the reconstruction of the regional vegetation for periods when the sedimentation occurred. In contrast to the record preserved in packrat middens, which contain intensive samplings of all local flora, the pollen record is more regional in scope and weighted heavily toward species producing large amounts of windborn pollen.

\section{Deciduous Forests of Eastern North America}

A remarkable picture of the dynamics of tree species of the eastern deciduous forest since the last glaciation is now emerging. Davis (1981a, 1983a, 1983b) presents maps with isopleths circumscribing study sites with similar dates for the first appearance of pollen of major tree genera or species. The invasion of trees, generally from south to north, after the glaciers melted is thus depicted (Fig. 3).

When maps for several trees are considered, 3 points stand out as strikingly evident: (1) the direction of migration was different for each species/genus, (2) the time of arrival at a given point was markedly different among species and/or genera, and (3) the rates of movement were surprisingly fast (Fig. 3, Table 2). Documented changes in distribution and abundance spanned the entire time period between the melting of the last continental glacier and the present. Rates of movement based on time increments between

Table 2. Time span of first occurrences in years before present (yr BP) of pollen of principle tree species/genera of the forests of eastern North America at the extreme ends of a south to north gradient (c.f. Fig. 3) and the calculated rate of migration (compiled from Davis 1981a, 1983a).

\begin{tabular}{|c|c|c|}
\hline Species & South & Migration rate \\
\hline Boreal Elements & $\ldots$ yr BP $\ldots$ & $\mathrm{m} / \mathrm{yr}$ \\
\hline $\begin{array}{l}\text { Picea spp. } \\
\text { Larix laricina } \\
\text { Pinus banksiana/resirosa } \\
\text { Abies balsamea }\end{array}$ & $\begin{array}{l}25,000 \text { to } 7,000 \\
23,000 \text { to } 7,000 \\
23,000 \text { to } 7,000 \\
21,000 \text { to } 7,000\end{array}$ & $\begin{array}{l}250 \\
250 \\
400 \\
200\end{array}$ \\
\hline $\begin{array}{l}\text { Deciduous Forest Elements } \\
\text { Pinus strobus } \\
\text { Quercus spp. } \\
\text { Ulmus spp. } \\
\text { Tsugu canadensis } \\
\text { Carya spp. } \\
\text { Acer spp. } \\
\text { Fagus grandifolia } \\
\text { Castanea dentata }\end{array}$ & $\begin{array}{l}14,000 \text { to } 2,000 \\
12,000 \text { to } 7,000 \\
17,000 \text { to } 6,000 \\
13,000 \text { to } 2,000 \\
15,000 \text { to } 4,000 \\
14,000 \text { to } 6,000 \\
15,000 \text { to } 4,000 \\
15,000 \text { to } 2,000\end{array}$ & $\begin{array}{l}300-350 \\
350 \\
250 \\
200-250 \\
200-250 \\
200 \\
200 \\
100\end{array}$ \\
\hline
\end{tabular}

isopleths range from $400 \mathrm{~m} / \mathrm{yr}$ for jack and red pine (Pinus spp.) to $100 \mathrm{~m} / \mathrm{yr}$ for chestnut [Castanea dentata H. (Marsh) Borkh.] (Table 2). These rates are quite similar to those estimated for creosotebush in the desert.

The conclusions drawn by Davis (1983a) are pertinent to our questions about balance and stability: “...various species of trees
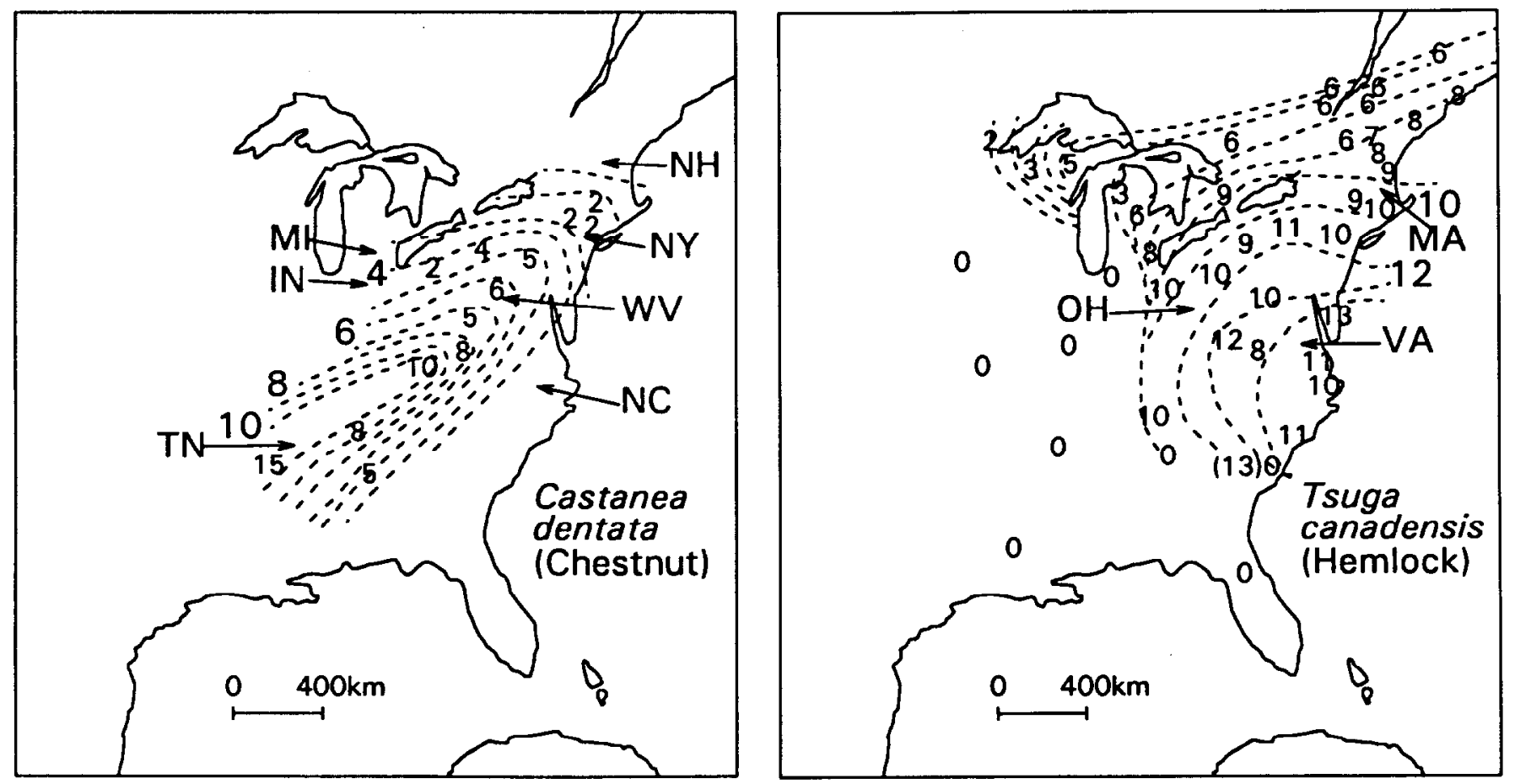

Fig. 3. Pollen isopleths of chestnut and hemlock showing migration of these species through time and the approximate range attained in the eastern United States by the time of the discovery of the New World. Small numerals represent time in thousands of years before present (BP) of the first appearance of the species in the pollen profile at that location. Numerals in large type apply to the lines that circumscribe areas of equal arrive times, in thousands of years BP. The orientation of the dashed lines indicates the direction of migration. The distance between the lines and the time of interval designation indicate the rate of migration. IN (Indiana), MA (Massachusetts), MI (Michigan), NC (North Carolina), NH (New Hampshire), NY (New York), OH (Ohio), TN (Tennessee), VA (Virginia), and WV (West Virginia). Modified from Davis (1983b). 
moved northward individualistically. Forest communities have represented fortuitous combinations of species during the holocene. Many modern communities are very young; they include dominant species that have grown locally for only a few thousand years.... Evolutionary processes that may have adapted co-occurring species to one another have had very little time in which to take effect."

Short-term change in forests at the local scale is well illustrated by Henry and Swan (1974). They considered the vegetational history of an undisturbed old growth stand in central New England. The forest's history since the mid 1600's was reconstructed from the meticulous analysis of age and relative positions of standing trees, dead trees down but unburied, and buried tree fragments. They found that 3 different forests had occupied the site over the last 300 years. A fire destroyed a forest of white pine (Pinus strobus L.), white oak (Quercus alba L.), and hemlock [ Tsuga canadensis L.) Carr] in approximately 1665 A.D. The forest that followed was dominated by white pine and hemlock until it was destroyed by 4 wind storms beginning in 1897 and culminating in a hurricane in 1938. The young forest that developed following the hurricane is dominated by hemlock, beech (Fagus grandifolia J.F. Ehrh.), red maple (Acer rubrum L.), and black birch (Betula lenta L.). Although the 3 forests have some elements in common, the differences among them suggest that the out-of-balance dynamics recorded in the palynological record persisted in the forests of eastern North America into the historical period on a local (community) scale.

The validity of extrapolating the imbalance of forests of eastern United States to other vegetation types may be questioned on the basis of their initial proximity to the Wisconsin ice sheet and the opportunity for invasion afforded by the exposure of bare surfaces as the ice retreated. An estimate of the dynamics of tropical forests would provide a test for such an objection since no such available void is hypothesized for the lower latitudes.

\section{Tropical Forests}

These magnificent forests enjoy a reputation for complex physiognomy and floristic diversity, which to many are synonymous with antiquity and balance. Tropical forests have been regarded as an end point in an ultimate plant succession, a world climax. However, the pollen record from tropical Central America shows much the same lack of species stability as was shown for the temperate forests to the north. The work of Alan Graham in the lowlands of Mexico is cited by Lewin (1984) as concluding that tropical forests should be regarded as "dynamic and ephemeral rather than stable and ancient." Lewin reviews research by Leyden (1984) in the lowlands of Guatemala and suggests that the "lush", moisture-loving, semievergreen, seasonal forest that now carpets the lowland" was not evident $11,000 \mathrm{yr}$ ago. Instead, the area was occupied by a juniper scrub. Lewin notes that the rate of change needed to transform the juniper scrub into the modern forest is impressive by itself but even more so in light of the probability that large portions of the presently forested areas must have regrown after having been cleared by the Mayan peoples between 3,000 and 400 years ago.

The search for ice age refugia where present day tropical forests spent the pleistocene glaciations has been in vain (Leyden 1984, Liu and Colinvaux 1985). The absence of contemporary plant assemblages in the fossil record at particular sites requires a dynamic movement of species from different places to those sites today. Lewin sees this as casting doubt on popular concepts of community identity. "This repeated reassembly as opposed to repeated regrowth of pristine communities, forces one to view the tropical forest as less of a cohesive natural unit than previous theory implied." Paleoecological data from the tropical highlands of Mexico show a similar history of changes in vegetation structure and species composition at higher altitudes (Straka and Ohngemach 1989).

The intuitively appealing notion that diversity confers stability has little if any support in current literature (Connel 1978, McIntosh 1980). In fact, Lewin (1984) maintains that "high diversity through instability not stability is how the equation reads." In regard to ecosystem balance and biotic integration, the tropical forests appear similar to temperate forests in lacking abstract identities that are faithfully replicated in either time or space.

\section{Plant Introductions and Extinctions in California}

Another perspective on the stability of species composition may be gained from analyses of regional floras and the changes in them that occur over time. The state of California is a prime candidate for such consideration because it is relatively well known floristically and has a cadre of botanists conscientiously making field observations. The earliest indication of establishment of foreign species in the state comes from the identification of plant fragments in the binding material used in making adobe brick for the construction of the first Spanish mission in San Diego in 1769. Redstem filaree [Erodium cicutarium (L.) L'Her.], curleydock (Rumex crispus L.), and sow thistle [Sonchus asper (L.) J. Hill] are 3 introduced species so identified (Hendry 1931). These early records, which date from the first European settlement, foreshadow a series of continuing waves of introductions and naturalizations of exotic plant species. As early as 1864, Bolander listed 109 species of grasses from the Central Valley of which 29 were foreign (cited by Burcham 1957). Subsequent state floras show that $7 \%$ of the species were considered introduced in $1925,14 \%$ in 1959 and $16 \%$ in 1968 (Table 3). Although differences among the tallies may

Table 3. Temporal increases in the number and percentage of introduced plant species in the vascular flora of California.

\begin{tabular}{|c|c|c|c|}
\hline \multirow[b]{2}{*}{ Year } & \multicolumn{2}{|c|}{ Introduced species } & \multirow[b]{2}{*}{ References } \\
\hline & $\begin{array}{l}\text { Number } \\
\text { reported }\end{array}$ & $\begin{array}{l}\text { Percent of } \\
\text { all species }\end{array}$ & \\
\hline 1925 & 298 & 7 & $\begin{array}{l}\text { Herriott \& Noldeke } 1956 \text { from } \\
\text { Jepson } 1925\end{array}$ \\
\hline 1940 & 526 & $?$ & Robbins 1940 \\
\hline 1959 & 800 & 14 & $\begin{array}{l}\text { Smith \& Noldeke } 1960 \\
\text { Munz \& Keck } 1959\end{array}$ \\
\hline 1968 & 975 & 16 & $\begin{array}{l}\text { Howell } 1972 \\
\text { from Munz } 1968\end{array}$ \\
\hline 1981 & 1,022 & 17 & $\begin{array}{l}\text { Smith et al. } 1981 \\
\text { Howell } 1972\end{array}$ \\
\hline
\end{tabular}

reflect changing taxonomic interpretations and increasing knowledge of floristic components, it is significant that the proportional increase in introduced species continues in an upward trend with time.

The very rapid encroachment of new species at the beginning of the historical period indicates the absence of initial stability in the system and perhaps what in Clementsian terms would be called a "postclimax" situation where changes in vegetation lagged behind changes in climate. Existing vegetation at the time of settlement was not well equilibrated with the physical environment and this marked disequilibrium resulted in increased opportunity for invasion and naturalization by new species preadapted to the prevailing conditions. Many such species in the California central valley grassland should, perhaps, be considered "new natives" because they exhibit a measure of ecological stability that ensures their continuance in facc of the natural processes of vegetational change (Heady 1977). Today it is estimated that over $50 \%$ of the vegetational cover of unimproved rangeland in the central valley is made 
up of exotic species (Burcham 1957, Heady 1977). Introduced species such as wild oats (Avena fatua L.), soft brome (Bromus mollis L.), and filaree (Erodium spp.) are major contributors to rangeland productivity. Others such as Klamath weed (Hypericam perforatum L.), medusahead (Elymus caput-medusae L.), and goatgrass (Aegilops triuncialis L.) are weeds that reduce forage yield.

The mix of introduced and native taxa displays proportional differences according to rank in the classification hierarchy (Table 4). The percentage of introduced families is low (6.8\%) in comparison to introduced species (16.2\%) while the percentage of introduced genera is high (24.8\%). The high incidence of introduced genera, around one fourth of the total, suggests that these taxa have phylogenies divergent enough from the native taxa to cause a substantial increase in the breadth of the biological diversity of the flora as a whole.

Table 4. Numbers of native and introduced taxa in the vascular flora of Californin according to taxonomic classification. Figures in parentheses indicate number of endemics in the category (Smith and Noldeke 1960, Noldeke and Howell 1960 and Howell 1972 as based on Munz and Keck 1959 and Munz 1968).

\begin{tabular}{llccc}
\hline \hline $\begin{array}{l}\text { Taxonomic } \\
\text { unit }\end{array}$ & $\begin{array}{c}\text { Native } \\
\text { taxa }\end{array}$ & $\begin{array}{c}\text { Introduced } \\
\text { taxa }\end{array}$ & $\begin{array}{c}\text { Total } \\
\text { taxa }\end{array}$ & $\begin{array}{c}\text { Percent } \\
\text { introduced }\end{array}$ \\
\hline Families & 155 & 12 & 167 & 6.8 \\
Genera & $857(29)$ & 282 & 1,139 & 24.8 \\
Species & $5,027(1,510)$ & 975 & 6,002 & 16.2 \\
$\begin{array}{l}\text { Specific and } \\
\text { Subsp. }\end{array}$ & $6,658(2,633)$ & 1,017 & 7,675 & 13.2 \\
\hline
\end{tabular}

The California Native Plant Society (CNPS) catalogues and evaluates the newly escaped exotics with regard to the threat they might pose to native species through the process of competitive exclusion (Smith 1979). The first list of "escapees" contained 326 species. Although most of these were among the 1,000 introduced species already considered in the references mentioned above, 44 were not, and these evidently represent recent naturalizations supplying the ongoing invasion. CNPS identified 6 species that appear aggressive enough to assume dominance in certain areas of native vegetation: Andean pampas grass [ Cortederia jubata (Lem.) Stapf.], French broom (Cytisus monspessulanus L.), Scotch broom [C. scoparius (L.) Link], gorse (Ulex europaeus L.), ice plant [Carpobrotus edulis (L.) Bolus.], and salt cedar (Tamarix ramosissma Ledeb.). A threat to native species is presumed if roles of dominance are assumed, especially if their potential habitat includes that of native species that are considered rare or endangered.

CNPS also identifies, maps, and evaluates the status of the less common or threatened native plants in the state (Smith et al. 1980). Presently, 1,394 species and subspecies, more than $20 \%$ of the natives, have been listed under this designation. The group was further characterized as those presumed extinct ( 44 species), those rare and endangered (680 species), those rare but not endangered (430 species), and those rare in California but more widely distributed outside the state ( 240 species).

There is no evidence to suggest that introduced species were in any way involved in the presumed extinctions. Those classifed as "presumed extinct" are of particular interest since they represent probable examples of species removed from ecosystems. Since the list was published in 1980 (2nd edition revised), 10 of the 44 species have been located alive in California, 6 have been determined to still exist in adjoining states or regions, 5 are described as subspecies of more generally occurring species, and several others initially collected from remote locations are thought by specialists to have a high probability of still occurring there. The case against any chance of recovery appears strong for about 6 species of the initial 44 presumed extinct (personal communication, $A$. Howard). None of the initial group were ever abundant, and most were known only from a single location and in some cases as a collection from 1 or 2 individual plants. It is unlikely that any of the probably extinct species ever played significant roles in the structure and function of the ecosystems of which they were a part. On the balance sheet of current species richness, one aspect of diversity, the impact of the 6 probable extinctions is far overshadowed by the introduction of 1,000 new species.

Many of the species listed as rare are on the fringe of successful establishment. In this regard, what taxonomists elect to call a species is of great significance. The plant species listed as endangered and / or rare are also, as might be surmised from the designations, only minor structural components of the ecosystems where they occur. Most are endemic, probably of recent origin (neoendemics) and belong to genera and families that exhibit a high degree of evolutionary activity. Examples are the members of the genus Eriogonum (Polygonaceae) with 51 rare species and varieties out of approximately 104 species and 50 varieties in the flora, and the genus Arctostaphylos (Ericaceae) with 37 rare or endangered species and subspecies out of approximately 43 species and 18 subspecies or varieties in the flora. The genus Astragalus (Leguminosae) contains 37 rare species and varieties out of a total of approximately 94 species and 32 varieties in the flora. The pattern suggests that many of these are recently derived from established species and that most failed to increase beyond one or a few individuals.

The general ecological profile of the rare native species contrasts sharply with that of the naturalized exotics. The latter have passed through the filter of repeated successful establishment. As a group, the naturalized exotics are more ecologically and economically important than the threatened and endangered natives. At this juncture, it is clear that species have been more readily added to than removed from the "fragile ecosystems" of highly industralized California. This has resulted in a marked increase in one measure of ecosystem diversity, floristic richness.

\section{Sudden Losses of Dominant Species}

\section{Inadvertant Biological Control}

Three naturally occurring events mimic experiments we might like to conduct to evaluate the effects of suddenly deleting important species. The effects of chestnut blight on American chestnut, Dutch elm disease on American elm (Ulmus americana L.), and an unknown suspect on eastern hemlock may be considered as "worst case" scenarios.

The American chestnut was until recently a dominant tree of the eastern deciduous forest of North America extending over a range of approximately 80 million ha. In 1904, a fungal pathogen [ Endothia parasitica (Murr.) P.J. \& H.W. And.] was discovered on chestnut trees in Bronx Park, New York City (Gravatt and Parker 1949). It spread rapidly and killed $80 \%$ of the chestnut tree boles in the eastern deciduous forest in less than $50 \mathrm{yr}$. This has been termed "perhaps the greatest single natural catastrophe in the annals of forest history" (MacDonald et al. 1978). The spread of the disease was so rapid that the decrease was essentially synchronous over the eastern forest region. The species has by no means been eliminated, but it persists only as sprouts and is now an understory shrub where it once was a major component of the tree canopy (McCormick and Platt 1980).

The effect of the chestnut blight on the forest ecosystem has not been described as a dramatic disruption of functional processes. The immediate consequence of the death of American chestnuts was the development of gaps in the energy-accumulating forest canopy. Ecosystem "goods" in terms of chestnut fruits (nuts) and 
available chestnut timber declined markedly. The demise of the chestnut was followed by a surge of growth by associated species which closed the gaps in the canopy in 10 to 20 years. Oaks (Quercus spp.) responded most quickly in Tennessee and Virginia (Woods and Shanks 1959, McCormick and Platt 1980) and cherry birch (Betula lenta L.) in the north, e.g., New Jersey and Connecticut (Good 1968, Davis 1981b). Through the years, hickory (Carya spp.) has increased in the south to the point of codominance with the oaks (McCormick and Platt 1980) while in the north the oaks have continued to increase at the expense of the birch (Davis 1983a). Other forest tree species such as maples (Acer spp.), ashes (Fraxinus spp.) and birches (Betula spp.) have also undergone population changes in the blight areas, as elsewhere.

Although projection of "recovery" to some presumed new climax is a common practice (Wood and Shanks 1959, McCormick and Platt 1980), the results must be viewed as illusionary if the expectation extends beyond the generation time of the longestlived dominants. After all, chestnut had occupied the forest in New York for a brief 2,000 years before the blight struck (Fig. 3). Based on life history considerations, 2,000 years is equivalent to only 3 or 4 generations, hardly enough cycles to establish much integration.

The functional stability of the eastern deciduous forest ecosystem is not dependent on a definite species composition but that the species comprising the system have the capacity for the performance of essential processes. In arguing a point similar to this, Slobodkin et al. (1967) noted that the demise of the American chestnut "has not left holes in our forests" and that "Not one mature chestnut can be put back without displacing plants of other species." The processes once performed by chestnut are now being carried out by other tree species. In terms of ecosystem "goods and services," the "goods" of oak, birch, beech, maple, and ash have been subsituted for the "goods" of chestnut and the "services" have remained about the same.

The Dutch elm disease "created more worldwide environmental concern than any other tree disease" and "has proven to be one of the most devastating tree diseases known to mankind" (Karnosky 1979). The effects on the American elm of the fungus Ceratocystis ulmi (Buismam) C. Moreau were similar to those presented for the American chestnut. American elm was a major component of the eastern deciduous forest at the time of European settlement. It was particularly abundant along streams and rivers throughout almost all of the deciduous forest region. In addition to being a major forest species, "nature's noblest vegetable" (Karnosky 1979) was a favored choice for shade tree plantings in cities and towns all across the country, especially in the northeast.

Dutch elm disease (DED) was unwittingly introduced to North America around 1930. It was first reported from Ohio, where it is believed to have arrived in diseased elm logs from Europe. It was soon found in New Jersey and New York (Karnosky 1979). By 1949 it was reported from natural forests and shade tree plantings from Massachusetts in the northwest to Virgina to the south and Indiana to the west (Swingle et al. 1949). Unlike the chestnut blight, it is spread by 4 species of elm bark beetles, 3 introduced (Scolytus multistriatus Marsh, S. scolytus Fabr. and S. pygmaeus Fabr.) and 1 native (Hylurgopinus rufipes Eichhoff) (Karnosky 1979). In areas where DED struck, elm death estimates ranged from $75 \%$ to 95\% of the population.

Like American chestnut, American elm sprouts prolifically. Karnosky (1979) concludes that "millions of root-sprouts are now developing in the original outbreak area, indicating that elms will continue to inhabit much of their original range-but not as dominant components which they once were" and further "resprouting of diseased elm will ensure that elms will continue to be important components of forest stands in north-temperate regions around the world."
Five to 10 years following the demise of canopy-size American elm in deciduous swamp communities in Michigan, black ash (Fraxinus nigra H. Marsh.), red maple and yellow birch (Betula alleghaniensis N.L. Britt.) became dominant in the tree layer and were filling the gaps left by the dead elms (Barnes 1976). Twentysix years after DED struck a mesic upland site in the same state, American elm still ranked first in importance value among forest trees but was declining relative to the oaks (Quercus spp.) and red maple (Richardson and Cares 1976). The "goods" have changed but the "services" have remained about the same. The recent decrease in importance of American elm appears to have a precedent in Europe, where elm pollen deposition rates decreased dramatically about 5,000 years BP. Several causes have been proposed, but the evidence increasingly points to an epidemic disease (Perry and Moore 1987).

Eastern hemlock is an evergreen conifer that has exhibited a consistent association with deciduous trees through time (Table 2). It also forms almost pure stands in parts of its range. Today there is no apparent threat to hemlock, but patterns in the pollen record (Davis 1981b, 1983a) suggest that its abundance in North America was severely decreased in prehistory, just as the abundance of elms decreased abruptly in Europe. Like other trees, it migrated north after the last glaciation but followed a distinctive northwesterly path (Fig. 3). About 5,000 years ago, it was widely represented as a major species in the regional vegetation. Approximately 4,800 years ago, there was a sudden and large decrease in the rate of hemlock pollen deposition. The change appears to be synchronous throughout the entire deciduous forest. Pollen rain from other tree species remained high or increased. Birch pollen increased immediately in the north, followed by an increase in oak pollen. Elsewhere, pollen deposition rates of various combinations of beech, hickory, maple, oak, and pine increased (Davis 1983a).

The decrease in deposition in hemlock pollen at 4,800 years ago and the subsequent compensating shifts in the pollen of associated species match closely the changes in production of chestnut pollen and the pollen of its associates in modern time caused by chestnut blight. This suggests strongly the involvement of some biological agent, a pathogen or an insect, in the prehistoric decrease of hemlock. Hemlock did not disappear completely during this episode but remained at low levels for about 1,000 years and then started to increase so that by around 3,000 years BP it had returned to a position of importance in the regional vegetation (Davis 1983a). Here again the "goods" of other species were substituted for the "goods" of hemlock while maintaining ecosystem processes or "services" at a nearly constant level.

\section{Biological Control of Weeds}

Intentional biological control programs designed to remove undesirable plants on rangelands may have results similar to the accidental case histories just discussed. Four selected examples, 2 representing native weeds and 2 representing introduced weeds, will be considered.

Manuka (Leptospermum scoparium Forstr.), a native shrub of New Zealand, is an aggressive invader of established grassland on both the North and South Islands. Its abundance greatly increased in historical times, particularly in areas cleared of trees for pastures. Pasture infestations were estimated at 2.8 million ha on the North Island and $\mathbf{0 . 6}$ million on the South Island, approximately $25 \%$ and $4 \%$ of the respective island areas (Hoy 1961). Biological control of manuka was considered only after the chance introduction of the mealybug Eriococcus orariensis Hoy from Australia was discovered on the South Island (Hoy 1949, 1961). E. orariensis was effective in killing infected plants over a period of years and acquired the designation "manuka blight" (Sewell 1949). Starting in 1946, the use of manuka blight was popularized in newspapers 
and was advertised for sale to farmers in 1948 (Hoy 1961). Its spread was fostered by man on both the North and the South Island at least through 1953. Thereafter, opposition to its use developed from those who feared irradication of the target native plant and possible damage to affected watersheds (Hoy 1961).

Manuka die-off was striking throughout its range at first but diminished markedly in places, particularly on the North Island, where the mealybug was parasitized by a fungus. Hoy (1961) concluded in this connection that "the recovery of $L$. scoparium in the North Island has been as spectacular as the initial control achieved by $E$. orariensis." The fungus had little effect in reducing the efficacy of the mealybug on the drier South Island or in the drier parts of the North Island. Effective control of manuka continued in these drier areas through 1960 (Hoy 1961). The concern over the possible irradication of $L$. scoparium in New Zealand proved premature since its continuance in the moister portions of its range now seems assured.

A series of significant vegetation structural changes during the manuka episode are related to shifts in both the goods and services (processes) provided by the ecosystem. "Goods" changed as forest trees were removed initially to increase forage production which in turn was suppressed by the invasion of manuka shrubs and then restored when the shrubs were killed by the introduced manuka blight. Physiological processes of trees, shrubs, and herbs are sufficiently different as to represent substantial shifts in ecosystem services as the dominant life form changed from one to another.

Two species of native pricklypear [Opuntia littoralis (Engelman) Cockerell and $O$. oricola Philbrick] on Santa Cruz Island, just off the coast of southern California, increased to pest proportions during the early part of this century. Biological control efforts were undertaken in the late 1930's using native mainland insects not found on the island (Goeden et al. 1967). Although the introduction of several insect genera was attempted, the primary success was attained with Dactylopius opuntiae Cockerell, a cochineal insect from Mexico via Australia and Hawaii. After the successful establishment of $D$. opuntiae in 1951, pricklypear decreased markedly in abundance and livestock grazing conditions improved greatly (Goeden et al. 1967, Goeden and Ricker 1981). However, scattered clumps of pricklypear are still found throughout the island and in some places in quantity (Goeden personal communication). In recent years, pricklypear mortality has decreased as predators of Dactyopis have gained entrance to the island. Goeden ascribes the initial effectiveness of $D$. opuntiae in killing pricklypear on Santa Cruz Island, as opposed to the adjacent mainland, to the initial absence of the insect's predators on the island. Over the years there has been a shift in the relative amounts of the 2 Opuntia species present in favor of $O$. oricola, which is less susceptible to damage by Dactylopius. Still, neither species has been eliminated from the island, and pricklypear will likely continue as a conspicuous component of the vegetation.

The increase and subsequent decrease in density of native pricklypears represent shifts both in the "goods" and "services" provided by the ecosystem. Structure changed from succulent to nonsucculent and the metabolism from CAM (crassulacean acid metabolism) to the common $\mathrm{C} 3$ type. This represents a shift in transpiration and carbon dioxide uptake from nighttime to daytime conditions and relates directly to how water, carbon, and other growth resources are processed.

The control of pricklypear cactus in Australia provides a favored example for textbooks and technical publications of how biological control can be applied in the field (Heady 1975). The campaign against pricklypear was undertaken in response to an enormous and alarming increase in abundance that occurred about the turn of the century. The principal organisms involved are 2 closely related species or varieties of pricklypear, Opuntia inermis DC. and $O$. stricta (Haworth) Haworth, from the Gulf Coast in North America, and the moth Cactoblastis cactorum Berg. from Argentina (Dodd 1940, Man 1970). The cacti were brought into Australia to be grown as hedges and were distributed widely for that purpose from about 1840 to 1870 . Their ability to spread caused apprehension in the 1880 's. By 1900 , an estimated 4 million ha were affected. The invasion rate accelerated after a drought in 1902 in which pricklypear was "freely fed" to livestock. At its peak in 1925, it was estimated that an area of 24 million ha had been invaded and that the rate of spread was on the order of 0.5 million ha/yr (Dodd 1940). In 1925, Cactoblastis cactorum was successfully introduced and distributed through the infected area. The results were dramatic. It was evident to Dodd that pricklypear would be controlled by 1928 . Most of the large pure stands of pricklypear were reduced to scattered plants, and $C$. cactorum continues to be effective in controlling $O$. inermis and $O$. stricta in much of the area. It is significant, however, that these pricklypears still persist throughout most of the area they once dominated (Man 1970, White 1981) and that they are still spreading, albeit at a slower rate (Haseler 1981). Haseler also points out the satisfactory control was never realized in central and southern New South Wales or coastal Queensland. The evidence suggests that pricklypear is well enough suited to the physical and biotic environments of Australia to persist indefinitely as a part of the natural vegetation. Perhaps it is a "new native." The changes in "goods" and "services" parallel those noted for Santa Cruz Island. A difference is that non-native pricklypear and its associated fauna persist as something new in the Australian landscape, as does Klamath weed in northwestern North America.

Klamath weed, or St. Johnsworth ( Hypericum perforatum L.), a perennial herb native of Europe and Asia, appeared in northwestern North America in the early 1900's. It spread rapidly and by 1940 had become a prominent component of rangeland vegetation over 2 million ha (Goeden 1978). It was an undesirable addition because it is toxic to livestock (Huffaker and Holloway 1949). Biological control efforts were undertaken in the early 1940's, and by 1945 a leaf-feeding beetle (Chrysolina guadrigemina Suffrian) from France was released in northern California. The results were phenomenal. Within a decade, Klamath weed was reduced an estimated 99\% (Huffaker and Kennett 1959). The greatest influence of the leaf beetle appears to have been in the central area of the Klamath weed infestation. Weed populations toward the margins of its range northward in Canada and southward in California were less affected.

The ecological position occupied by Klamath weed in the natural landscape changed under the influence of its insect predator from fully sunlit, open habitat to partially shaded understory (Huffaker and Kennett 1959). But the target species still persists throughout the range it attained during the period of its rapid invasion. Thus, Klamath weed is still more abundant than many native species in the flora, and it now appears to be a permanent member of northwestern rangeland vegetation even in the presence of its imported enemies and the competition of presumably welladapted native plants.

The initial invasion of Klamath weed brought about a change in the specific "goods" and "services" provided by the ecosystem. Structural changes, though not as great as for manuka and pricklypear, were associated with a shift in the quality of herbaceous plants for grazing. Klamath weed replaced desirable grasses until exotic insects reduced its abundance and shifted the "goods" and "services" back to grasses and grass processes.

None of the 610 biological control projects conducted on Earth to date, involving 94 weed species in 53 countries (Julien 1987) has eliminated any plant species completely. Insects have been employed successfully to suppress pricklypear cacti at least 19 times (Goeden 
1978). In none of these does it appear that weedy pricklypears, native or introduced, were eliminated from a landscape. The recurring suggestions that the plant Tribulus cristoides L. has been eliminated in Hawaii is in error (G. Funasaki, personal communication), although such an extinction has been reported for an endemic snail on the island of Moorea in French Polynesia (Clarke et al. 1984). That is not to say that extinction has never occurred for plants, but the historical evidence suggests that neither insects nor diseases are likely to eliminate ecologically successful species, whether native or introduced.

\section{Conclusions}

The view of vegetation dynamics that emerges from the information presented on creosotebush in deserts, the eastern deciduous forests, tropical forests, California floristics and episodes of biological control, is strikingly different from the view of many practitioners of vegetation management. The contrasts to a paradigm of ancient, stable, delicately balanced, Clementsian climax communities with all parts essential and evolved in place are: (1) the natural vegetation systems reviewed here exhibit ongoing change in species composition in time and space; both the paleoecological and historical data show that plant communities are continually being assembled and reassembled in terms of species makeup; (2) vegetation (ecosystem) stability is more associated with physiognomy and functional processes than species composition; (3) the flux rate in major plant species has been too fast to allow for the number of generations usually postulated as necessary for the refined development of co-evolutionary integrated, biologically regulated and delicately balanced ecosystems of landscape scale; (4) ecosystems appear highly susceptible to invasion by exotic species which then persist as major components of the vegetation, but with fluctuations in importance over relatively short time frames; (5) the relative importance of native and exotic species in ecosystems has and can be changed markedly and quickly by biological agents, but ecosystems appear to adjust rapidly in restoring productive capacity and functional processes without disastrous consequences. Shifts in structure may or may not be involved. Inadvertant biological control episodes in eastern deciduous forests had no effect on structure. Furthermore, neither natural nor intentional biological control episodes have completely eliminated a plant species from an ecosystem, whether native or introduced. Whether in the context of biological or other control methods, Lugo (1990) was correct in writing that "eradicating organisms from nature is not as simple as one might be led to believe by the dogma that if a species is an exotic it is inherently evil and therefore a candidate for eradication."

An unbiased appraisal of ecological plant performance suggests that no special significance should be attributed to the label "native." Clearly, the status of nativity for plant species making up today's natural vegetation is relative. Furthermore, the evidence presented indicates that other environmental and biological factors weigh heavily in determining vegetation composition. This is contrary to a common assumption that the dominance of undesirable plants on rangelands always serves as evidence of overgrazing by livestock and that an elimination or reduction in grazing pressure will result in the reduction of the undesirable species and a return to "climax" species composition. Indeed, Harris (1988) contends that pure or nearly pure plant stands whether native or introduced are indicative of low herbivore pressure and that the introduction of appropriate insect herbivores will result in the decrease of dominance and an increase in plant diversity.

Biological invasions by exotic plants change species composition and may alter structure, but they rarely have dramatic ecosystem-level effects (Vitousek 1990) even in the case of California, where over 1,000 such invasions occurred over a relatively brief period of time. Vitousek cites examples to the contrary, but believes "that the majority of successful invasions do not alter large-scale ecosystem properties and processes in a meaningful way." Only those invasions which have had an impact even come to our attention, and those are a very small proportion of the total.

We conclude that the sanctity attributed to climax vegetation because it is natural, repeatable, and stable in species composition is without merit. We find no evidence that successful, productive communities consist mostly of species that evolved together and developed complex mechanisms for co-existing in a delicate balance within a narrow range of biotic variation. Dominant species appear to be interchangeable, within and among functional groups.

Clearly, the role man has played in contributing to dynamic change in vegetation has been on a grand scale and is of unquestionable significance (i.e., Bahre 1991). Some question man's right and capacity to manipulate the "natural environment" and advocate a "hands-off" approach. But the paleoecological and biogeographical sequences reviewed above suggest that there are few, if any, truly stable and "natural" plant assemblages. We must now be bold enough to accept the challenge of shaping and synthesizing new ecosystems, even in the "natural" environment. The structuring and restructuring of ecosystems will involve the visualization of appropriate arrangements of functional processes in time and space. Suites of plant species exhibiting the needed physiognomical, phenological, physiological, and phytosociological characteristics would need to be mixed with the appropriate microbes, invertebrates, and higher animals. This task is currently made difficult by traditions and practices as much as by deficiencies in our understanding of ecosystem processes. But an important step in this direction can be taken through more careful utilization of current theory of the dynamics of natural vegetation. Whether a correct, simple theory of vegetation dynamics will be developed or not is open to question. What is clear is that many of the expectations associated with the species-constant climax concept are incorrect and, thus, point us in the wrong direction. The popular perception of balance in nature persists in most fields of applied ecology and resource management to the detriment of establishment realistic goals and guides.

\section{Literature Cited}

Allee, W.C., A.E. Emerson, O. Park, T. Park, and K.P. Schmidt. 1949. Principles of animal ecology. W.B. Saunders, Philadelphia, Penn.

Andres, L.A. 1981a. Biological control of naturalized and native plants: conflicting interests. p. 341-349 In: Papavizas, G.C. (ed.), Biological control in crop production. BARC Symp. No. 5., Beltsville, Md. Allanheld, Osmun, Totowa, N.J.

Andres, L.A. 1981b. Conflicting interests and biological control of weeds. p. 11-20. In: Delfosse, E.S. (ed.), Proc. V Int. Symp. Biol. Contr. Weeds, CSIRO, Brisbane, Australia.

Austin, M.P., and T.M. Smith. 1989. A new model for the continuum concept. Vegetatio 83:35-47.

Bahre, C.J. 1991. A legacy of change: Historic human impact on vegetation of the Arizona Borderlands. Univ. Arizona Press, Tucson.

Barnes, B.U. 1976. Succession in deciduous swamp communities of southern Michigan formerly dominated by American elm. Can. J. Bot. $54: 20-24$.

Bazzaz, F.A., and K. Garbutt. 1988. The response of annuals in competitive neighborhoods: effects of elevated $\mathrm{CO}_{2}$. Ecology 69:937-946.

Bell, A. 1983. Native plants facing extinction. ECOS 37:21-26.

Branson, F.A. 1987. Vegetation changes on western rangelands. Range Monog. 2. Soc. Range Manage., Denver, Colo.

Buffington, L.C., and C. Herbel. 1965. Vegetation changes on a semi-desert grassland range. Ecol. Monog. 35: 139-164.

Burcham, L.L. 1957. California rangeland. An historico-ecological study of the range resource of California. Div. Forests, Dept. Natur. Resources, State of California, Sacramento.

Clarke, B., J. Murray, and M.S. Johnson. 1984. The extinction of endemic species by a program of biological control. Pacific Sci. 38:97-104. 
Clements, F.E. 1916. Plant succession: An analysis of the development of vegetation. Carnegie Inst. Pub. 242. Washington, D.C.

Clements, F.E. 1920. Plant indicators. The relation of plant communities to process and practice. Carnegie Inst. Pub. 290. Washington, D.C.

Cole, K.L. 1986. The lower Colorado River Valley: A Pleistocene desert. Quat. Res. 25:392-400.

Cole, K.L., and R.H. Webb. 1985. Late Holocene vegetation changes in Greenwater Valley, Mojave Desert, California. Quat. Res. 23:227-235.

Connell, J. 1978. Diversity in tropical rainforests and coral reefs. Science 199:1302-1310.

Cordo, H.A., and C.J. DeLoach. Insects that attack Larrea spp. (Zygophyllaceae) in Argentina and their potential for biological control. Environ. Ent. (in press).

Davis, M.B. 1981a. Quaternary history and the stability of deciduous forests. p. 132-177. In: D.C. West, H.H. Shugart, and D. B. Botkin (eds.), Forest succession. Springer-Verlag, N.Y.

Davis, M.B. 1981b. Outbreaks of forest pathogens in Quarternary history. Proc. IV Int. Palynol. Conf. 3:216-227.

Davis, M.B. 1983a. Holocene vegetational history of the eastern United States. p. 166-181. In: Wright, H.E. (ed.), Late Quarternary environments of the United States. Vol. 2. Chap. 11.

Davis, M.B. 1983b. Quaternary history of deciduous forests of eastern North America and Europe. Ann. Missouri Bot. Garden 70:550-563.

Davis, M.B. 1989. Address of the Past President: Insights from paleoecology on global change. Bull. Ecol. Soc. 70:222-228.

Dodd, A.P. 1940. The biological campaign against prickly pear. The Commonwealth Prickly Pear Board. Queensland Gov. Printer, Brisbane.

Dyksterhuis, E.J. 1946. The vegetation of the Fort Worth Prairie. Ecol. Monog. 16:1-29.

Dyksterhuis, E.J. 1949. Condition and management of rangeland based on quantitative ecology. J. Range Manage. 2:104-115.

Ellison, L. 1954. Subalpine vegetation of the Waxatch Plateau, Utah. Ecol. Monog. 24:89-184.

Emanuel, W.R., H.H. Shugart, and M.P. Stevenson. 1985. Climatic change and the broad scale distribution of terrestrial ecosystem complexes. Clim. Change 7:29-43.

Ehrlich, P.R. 1990. Habitats in crisis: Why should we care about the loss of species. Forest Ecol. and Manage. 35:5-11.

Gleason, H.A. 1926. The individualistic concept of the plant association. Torrey Bot. Club Bull. 53:7-26.

Gleason, H.A., and A. Cronquist. 1964. The natural geography of plants Columbia Univ. Press, N.Y.

Goeden, R.D. 1978. Biological control of weeds. Part II. p. 361-506. In: Clausen, C.P. (ed.), Introduced parasites and predators of arthropod pests and weeds: A world review. USDA, Agr. Res. Serv., Agr. Handbk. 480.

Goeden, R.D., C.A. Fleschner, and D.W. Ricker. 1967. Biological control of prickly pear cacti on Santa Cruz Island, California. Hilgardia 38:579-606.

Goeden, R.D., and D.W. Ricker. 1981. Santa Cruz Island-revisited. Sequential photography records the causation, rates of progress, and lasting benefits of successful biological weed control. p. 355-365. In: Del Fosse, E.S. (ed.), Proc. V Int. Symp. Biol. Contr. Weeds, CSIRO, Brisbane, Australia.

Good, N.F. 1968. A study of natural replacement of chestnut in six stands on the highlands of New Jersey. Bull. Torrey Bot. Club 95:240-253.

Graham, R.W., and E.C. Grimm. 1990. Effects of global climate change on the patterns of terrestrial biological communities. Trends Ecol. Evol. 5:289-292

Gravatt, G.F., and D.E. Parker. 1949. Introduced tree diseases and insects. p. 446-452. In: Trees. The Year Book of Agriculture. USDAU.S. Gov. Print. Off., Washington, D.C.

Haseler, W.H. 1981. Lessons from early attempts at biological control of weeds in Queensland. p. 3-9. In: Del Fosse, E.S. (ed.), Proc. V. Int. Symp. Contr. Weeds, CSIRO, Brisbane, Australia.

Harris, P. 1988. Environmental impacts of weed-control insects. Bioscience $38: 542-548$.

Heady, H.F. 1975. Rangeland management. McGraw-Hill, N.Y.

Heady, H.F. 1977. Valley grassland. p. 491-514. In: M.E. Barbour and J. Major (eds.), The terrestrial vegetation of California. John Wiley and Sons, N.Y.

Hendry, G.W. 1931. The adobe brick as a historical source. Agr. Hist. 5:110-127.

Henry, J.D., and J.M.A. Swan. 1974. Reconstructing forest history from live and dead plant material-an approach to the study of forest succession in southwest New Hampshire. Ecology 55:772-783.
Herrott, L., and A.M. Noldeke. 1956. A numerical summary of the vascular plants of California. Leafl. West. Bot. 8:58-59.

Howarth, G. 1983. Classical biocontrol: panacea or pandora's box. Proc. Hawaiian Ent. Soc. 24:239-244.

Howell, J.T. 1972. A statistical estimate of Munz' supplement to a California flora. The Wasman J. Biol. 30:93-96.

Hoy, J.M. 1949. Control of Manuka by blight. New Zealand J. Agr. 79:321-324.

Hoy, J.M. 1961. Eriococcus orariensis Hoy and other Coccoidea (Homoptera) associated with Leptospermum Forst. species in New Zealand. Dept. Sci. and Ind. Res. Bull. 141, New Zealand Univ.

Huffaker, C.B., and J.K. Hollowry. 1949. Changes in range plant population structure associated with feeding of imported enemies of Klamath weed (Hypericum perforatum L.). Ecology 30:167-175.

Huffaker, C.B., and C.E. Kennett. 1959. A ten-year study of vegetational changes associated with biological control of Klamath weed. J. Range Manage. 12:69-82.

Hunziker, J.H., P.A. Palacios, A.G. DeValesi, and L. Poggio. 1972. Species disjunctions in Larrea: Evidence from morphology, cytogenetics, phenolic compounds and seed albumins. Ann. Missouri Bot. Garden 59:224-233.

Idso, S.B., and J.A. Quinn. 1983. Vegetation redistribution in Arizona and New Mexico and response to a doubling of the atmospheric $\mathrm{CO}_{2}$ concentrations. Climat. Pub. Pap. 17. Arizona State Univ., Tempe.

Jepson, W.L. 1925. A Manual of the flowering plants of California. Univ. California Press, Berkeley.

Johnson, H.B. 1964. Changes in the vegetation of two restricted areas of the Wasatch Plateau as related to reduced grazing and complete protection. M.S thesis, Brigham Young Univ. Provo, Ut.

Johnson, H.B. 1976. Vegetation and plant communities of southern California deserts-A functional view. p. 125-164. In: Latting, J. (ed.) Plant communities of Southern California. California Native Plant Soc. Spec. Pub. 2.

Johnson, H.B., and F.C. Vasek. 1975. Some growth relationships of creosotebush (Larrea tridentata) in the California desert. p. 145. In: Stutz, H.C. (ed.), Proc. Symp. Wildland Shrubs. USDA, Forest Serv., Provo, Ut.

Julien, M.H., ed. 1987. Biological control of weeds-A world catalogue of agents and their target weeds. 2nd ed. C A B Int., Wallingford, UK.

Karnosky, D.F. 1979. Dutch elm disease: A review of the history, environmental implications, control and research needs. Environ. Conserv. 6:311-322.

King, T.J. 1976. Late Pleistocene-early Holocene coniferous woodlands in Lucerne Valley region, Mojave Desert, Calif. Great Basin Natur. 36:227-238.

Lewin, R. 1984. Fragile forests implied by Pleistocene pollen. Science 226:36-37.

Leyden, B.W. 1984. Guatemalan forest synthesis after the Pleistocene aridity. Proc. Nat. Acad. Sci. (U.S.) 81:4856-4859.

Liu, K., and P.A. Colinvau. 1985. Forest changes in the Amazon Basin during the last glacial maximum. Nature 318:556-557.

Lugo, A.E. 1990. Removal of exotic organisms. Conserv. Biol. 4:345.

MacDonald, W., F.C. Cech, J. Luchok, and C. Smith (eds.). 1978. Proc. Amer. Chestnut Symp. West Virginia Univ., Morgantown, W. Va.

Mack, R.N. 1981. Invasion of Bromus tectorum L. into western North America: An ecological chronicle. Agro-Ecosystems 7:145-165.

Man, J. 1970. Cacti naturalized in Australia and their control. Dep. of Lands, Queensland.

Mayeux, H.S., H.B. Johnson, and H.W. Polley. Global change in vegetation dynamics. p. 62-74. In: Proc. Nat. Noxious Range Weed Conf., Logan, Ut. Westview Press, Boulder, Colo. (in press).

McCormick, J.F., and R.B. Platt. 1980. Recovery of an Appalachian forest following the chestnut blight or Catherine Keever, you were right. Amer. Midland Natur. 104:264-273.

McIntosh, R.P. 1980. The relationship between succession and the recovery process. p. 11-62. In: Cairns, J., Jr. (ed.), The recovery process in damaged ecosystems. Ann Arbor Sci., Ann Arbor, Mich.

Meeker, D.O., and D.L. Merkel. 1984. Climax theories and a recommendation for vegetation classification. J. Range. 37:427-429.

Miles, J. 1979. Vegetation dynamics. Chapman and Hall Ltd., London.

Munz, P.A. 1968. Supplement to a California flora. Univ. California Press, Berkeley.

Munz, P.A., and D.D. Keck. 1959. A California flora. Univ. California Press, Berkeley.

Noldeke, A.M., and J.T. Howell. 1960. Endemism and a California flora. Leaflets West. Bot. 9:124-127. 
Overdieck, D., and F. Reining. 1986. Effect of atmospheric $\mathrm{CO}_{2}$ enrichment on perennial ryegrass (Lolium perenne L.) and white clover (Trifolium repens $\mathrm{L}$.) competing and managed model-ecosystems. Acta Oeco1./ Oecol. Plant. 7:357-366.

Pemberton, R.W. 1984. Native plants as targets for biological control. Abstr., VI Int. Symp. Biol. Contr. Weeds, Vancouver, Canada.

Perry, I., and P.D. Moore. 1987. Dutch elm disease as an analogue of Neolithic elm decline. Nature 326:72-73.

Peters, R.L. 1990. Effects of global warming on forests. Forest Ecol. Manage. 35:13-33.

Pimentel, D., E. Garnick, A. Berkowitz, S. Jacobson, S. Napolitan, P. Black, S. Valdes-Cugliano, B. Vinzant, E. Hudes, and S. Littman. 1980. Environmental quality and natural biota. Bioscience 30:750-755.

Price, P.W. 1975. Insect ecology. John Wiley and Sons, N.Y.

Richardson, C.J., and C.W. Cares. 1976. An analysis of elm (Ulmus americana) mortality in a second-growth hardwood forest in southeastern Michigan. Can. J. Bot. 54:1120-1125.

Robbins, W.W. 1940. Alien plants growing without cultivation in California. Calif. Agr. Exp. Sta. Bull. 637.

Sampson, A.W. 1919. Plant succession in relation to range management. USDA Bull. 791.

Sampson, A.W. 1923. Range and pasture management. John Wiley and Sons, Inc., London.

Sewell, T.G. 1949. Manuka blight survey. New Zealand J. Agr. 79:101-104. Slobodkin, L.B., F.E. Smith, and N.G. Hairston. 1967. Regulation in terrestrial ecosystems, and implied balance of nature. Amer. Natur. 101:109-124.

Smeins, F.E. 1983. Origins of the brush problem-a geological and ecological perspective of contemporary distributions. p. 5-16. In: Proc. Brush Manage. Symp., Soc. Range Manage., Texas Tech Univ., Press, Lubbock.

Smith, G.L., and A.M. Noldeke. 1960. A statistical report on a California flora. Leaflets West. Bot. 9:117-132.

Smith, J.P., Jr., J. Cole, and J.O. Sawyer, Jr. 1980. Inventory of the rare and endangered vascular plants in California. Calif. Native Plant Soc. Spec. Pub. 1 (2nd ed.).

Smith, M.N. 1979. Report of escaped exotics committee. Fremontia 6:18-19.

Soil Conservation Service. 1976. National Range Handbook. USDA. Washington, DC.

Spaulding, W.G. 1980. The presettlement vegetation of the California Desert. Contract Rep., BLM Desert Plan Staff. BLM Calif. State Office, USDI.

Spaulding, W.G. 1990. Vegetation dynamics during the last deglaciation, southeastern Great Basin, U.S.A. Quat. Res. 33:118-203.

Straka, H., and D. Ohngemach. 1989. Late Quaternary vegetation of the Mexican highland. Plant System. Evol. 162:115-132.

Sternberg, L. 1976. Growth forms of Larrea tridentata. Madrono 23:408-417.

Swingle, R.U., R.R. Whitler, and E.G. Brewer. 1949. Dutch elm disease. p. 451-452. In: Trees, the Yearbook of Agriculture. USDA, U.S. Gov. Print. Off., Washington, D.C.

Temple, S.A. 1990. The nasty necessity, eradicating exotics. Conserv. Biol. 4:113-115.

Vale, T.R. 1982. Plants and people: vegetation change in North America. Assoc. Amer. Geographers. Washington, D.C.

Van Devender, T.R. 1977. Holocene woodlands in the southwest deserts. Science 198:189-192.

Van Devender, T.R. 1986. Pleistocene climates and endemism in the Chihuahuan Desert flora. In: M. Powell (ed.), Second Chihuahuan Desert Symp. Chihuahuan Desert Res. Inst., Alpine, Tex.
Van Devender, T.R., J.L. Betancourt, and M. Wimberly. 1984. Biogeographic implications of a packrat midden sequence from the Sacramento Mountains, south-central New Mexico. Quat. Res. 22:344-360.

Van Devender, T.R., and W.G. Spaulding. 1979. Development of vegetation and climate in the southwestern United States. Science 204:701-710.

Van Devender, T.R., and L.J. Toolin. 1983. Late Quaternary vegetation of the San Andres mountains, Sierra County, New Mexico. In: P.L. Eidenbach (ed.), The prehistory of Rhodes Canyon. Human Systems Res., Inc., Tularosa, N.M.

Vasek, F.C. 1980. Cresotebush: long-lived clone in the Mojave Desert. Amer. J. Bot. 67:246-253.

Vasek, F.C., H.B. Johnson, and D.H. Eslinger. 1975. Effects of pipeline construction on creosotebush scrub vegetation of the Mojave Desert. Madrono 23:1-13.

Vitouselk, P.M. 1990. Biological invasions and ecosystem processes: towards an integration of population biology and ecosystem studies. Oikos 57:7-13.

Weaver, J.E., and F.E. Clements. 1938. Plant ecology. McGraw-Hill, N.Y.

Wells, P.V. 1966. Late Pleistocene vegetation and degree of pluvial climatic change in the Chihuahuan Desert. Science 153:970-975.

Wells, P.V. 1974. Post-glacial origin of the present Chihuahuan Desert less than 11,500 years ago. p. 67-83. In: Wauer, R.H. and D.N. Riskind (eds.), Trans. Symp. Biological Resources of the Chihuahuan Desert Region, United States and Mexico. Sul Ross State Univ., Alpine, Tex. U.S. Nat. Park Ser. Trans. and Proc. Ser. 3:67-83.

Wells, P.V. 1976. Macrofossil analysis of wood rat (Neutoma) middens as a key to the quaternary vegetation history of arid America. Quat. Res. 6:223-248.

Wells, P.V. 1983. Paleobiogeography of Montane islands in the Great Basin since the last glaciopluvial. Ecol. Monog. 53:341-382.

Wells, P.V., and R. Berger. 1967. Late Pleistocene history of coniferous woodland in the Mojave Desert. Science 155:1640-1647.

Wells, P.V., and J.H. Hunziker. 1976. Origin of the creosotebush (Larrea) deserts of southwestern North America. Ann. Missouri Bot. Garden 63:843-861.

Wells, P.V., and C.D. Jorgensen, 1964. Pleistocene woodrat middens and cimatic change in Mojave Desert: A record of juniper woodlands. Science 143:1171-1174.

Westman, W.E. 1977. How much are nature's services worth? Science 197:960-964

Westman, W.E. 1978. Measuring the inertia and resistance of ecosystems. BioScience 28:705-710.

White, G.G. 1981. Current status of pricklypear control by Cactoblastis cactorum in Queensland. p. 609-616. In: Del Fosse, E.S. (ed.), Proc. V Int. Symp. Biol. Contr. Weeds, CSIRO, Brisbane, Australia.

Woods, R.W., and R.E. Shanks. 1959. Natural replacement of chestnut by other species in the Great Smoky Mountains National Park. Ecology 40:349-361.

World Wildlife Fund. 1988. Abstracts of presentations at the conference Consequences of the Greenhouse Effect for Biological Diversity, Oct. 4-6, 1988. World Wildlife Fund, 1250 Twenty-fourth St., Washington, D.C.

Yang, T.W. 1970. Major chromosome races of Larrea divaricata in North America. J. Arizona Acad. Sci. 6:41-45.

York, J.C., and W.A. Dick-Peddie. 1969. Vegetation changes in southern New Mexico during the past hundred years. p. 157-166. In: W.G. McGinnies and B.J. Goldman (eds.), Arid lands in perspective. Univ. Arizona Press, Tucson. 